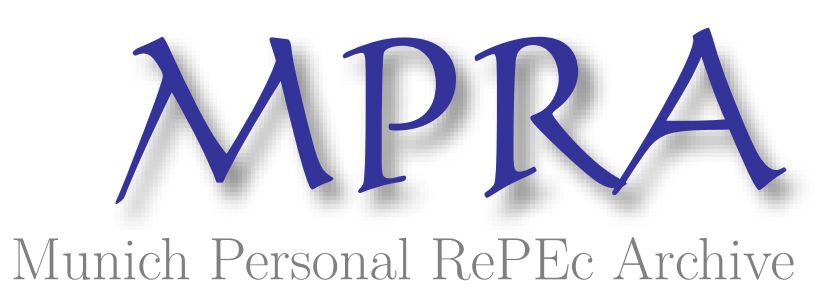

\title{
The Problem of Money Illusion in Economics
}

Erber, Georg

DIW Berlin - German Institute for Economic Research

15 July 2010

Online at https://mpra.ub.uni-muenchen.de/24246/

MPRA Paper No. 24246, posted 07 Aug 2010 02:17 UTC 


\section{The Problem of Money Illusion in Economics}

\section{Introduction}

In economic theory and analysis one key assumption in mathematical models is always to assume that there is no money illusion, i.e. economic agents can successfully dissect real and money values appropriately. This gives the opportunity to separate the economic spheres of real goods and services from those of the monetary valuation of such goods and services, i.e. asset markets. This dichotomy however contributes to a misunderstanding of the interdependencies between both spheres. Money is even considered in this analytical framework only to be another good which acts as a numéraire to standardize the valuation in a common accounting unit. Because of the convenience for analytical research it has become something like a dogma for good and bad economics. Theories excluding money illusion are good economic theories; those assuming money illusion are bad economic theories, because the latter lead to irrational behaviour and false conclusions about the fundamentals of a market oriented economic system. However, money illusion is an essential ingredient of financial markets which just reflect the intrinsic inconsistencies in the valuation process of financial market assets. Abstracting from money illusion misleads the theoretical economists to believe in an ideal world of efficient financial markets and overlook the inherent financial instability of asset markets.

James Tobin (1972, p.3), a nobel laureate in economics, went as far, by making the statement that: "An economic theorist can, of cause (sic! G.E.), commit no greater crime than to assume money illusion." This is an expression of overconfidence of the economist profession in the validity of one central postulate of economic reasoning about markets as institutions to coordinate social interactions related to goods and services. With money illusion embodied in economic analysis there will be market failures in the sense that they cannot establish justice in a society based on the market exchange mechanism. False trading, i.e. accepting in the 
exchange process prices which are out of equilibrium and non-converging towards an equilibrium in a tâtonnement process à la Walras (1874), has the frightening consequence that most of the theoretical explanations common in current economic textbooks and theoretical economic models presented there break down.

Fundamentalism, i.e. dismissing some of the fundamental axioms of economic theories, in the economic profession was always something which led normally to the exclusion from the profession. This in particular had also the consequence that the person who challenged these assumptions had to be aware to face a professional ban, e.g. dismissal as a university lecturer. It needed well established top academic economists to change this situation. The incentive system of academic economics is more or less: "Please leave the basic axioms of our theoretical foundations untouched otherwise you could face excommunication from our discipline and will be outlawed from the career track.

Opening the box of Pandora of axioms in economic theory was and still is for most economists therefore strictly forbidden. Those who do so where considered heretics in the religious sense and often dismissed as members of the economist profession. This attitude has much in common with religions who expect from there disciples that the credo of religious beliefs that cannot be questioned without losing the faith in the religious belief. If Jesus is not the son of god, you cannot be a Christian, or if you believe that Mohammed is not the prophet of god, you cannot be Muslim etc. If you dismiss the fundamental beliefs of economists that there is no money illusion you cannot be any longer an academic economist. This has only changed very slowly with the advent of a more on empirical evidence based economic research which led to the behavioural economics revolution over the last two decades (see e.g. Thaler 1992).

The analytical separability of monetary and the real world economics, however, have been more and more challenged in the current economic debate which accepts money illusion as a possibility in human behaviour (see e.g. Fehr, Tyran 2001). It is also no accident that the first area of questioning the rationality assumption of no-money-illusion emerged in the area of finance and led to the development of theories of behavioural finance (Akerlof, Shiller 2009, Malkiel 2003). They directly attacked the efficient market hypothesis (EMH) which was canonized $^{1}$ before by academic economists like Fama (1970). This schism between those who believe in EHM and those who don't has not been settled yet.

\footnotetext{
${ }^{1}$ The efficient-market hypothesis was developed by Professor Eugene Fama at the University Of Chicago Booth School Of Business as an academic concept of study through his published Ph.D. thesis in the early 1960s at the
} 
Again like in schisms in religious schools both communities coexists at the academic faculties, but each would like to drive the other out, where possible. Financial markets are in particular challenging for believers in the EHM because there exist no natural frictions as in real world commodity markets. Contracts on financial markets especially nowadays after these markets are primarily executed via electronic computer networks on trading platforms deliver instantaneous information around the globe. Prices for financial assets are seemingly accessible instantaneously. If those markets fail to be efficient, how much more the others will do so who face many more inertia due to a less global information exchange infrastructure and transportation costs to deliver them from their origin to their destinations? One might therefore consider the invalidity of the EMH in the area of financial markets to be an experimentum crucis for the validity of the EMH for any kind of market system.

Money seems in particular since it has become fiat money, i.e. not bound to the real commodity like silver and gold, as a medium of exchange a particular challenge for economic analysis since it poses another significant valuation problem to a society. The most important is the inflation-deflation-nexus. Another related phenomenon hard to explain is involuntary unemployment.

From a behavioural point of view general excess supply or demand for money needs to be explained by institutional failures like a central bank creating too much or too little liquidity (see e.g. Friedman, Schwartz 1971). In labor markets again institutional settings are used to explain their imperfections. This means that not the rational decision making based on money values is flawed, but the institutions like a central bank is flawed by following wrong monetary policies or trade unions are blamed to set non-market-clearing too high wage levels. Wage adjustments in labor markets are as well a standard example for downward stickiness of wages creating since Keynes (1936) a whole bunch of literature about strategies to accomplish a better employment situation by taking into account the empirical finding of wage-rigidities.

In a perfectly rational environment of homo oeconomicie contracting instantaneously and independently from each other this should lead to price adjustments in market prices with respect to an increase in the general price level or full-employment in the labor market. The observable inertia in the delayed adjustment to this result was simply explained by information problems or adjustment costs of price adjustment. Institutions which distort this free market equilibrium are generally considered harmful and damaging the social welfare. Therefore deregulation, i.e. liberalization from regulations, or self-regulation has always been

same school. It was widely accepted up until the 1990s, when behavioral finance economists, who were a fringe element, became mainstream. 
the war cry of orthodox market liberals in academia. To avoid institutional failures by any kind of collective market regulation the solution suggested by market radicals is always like a Buddhist mantra - let markets work it out by themselves or in French laissez-faire or laissezaller. That what you finally get if you keep to this simple rule is the social welfare optimum. Any interference via regulation to set prices or quantities leads to harmful results, i.e. welfare losses.

\section{From harmonia mundi of a general equilibrium in economics towards an evidence based economics supported by empirical experiments}

When asking for the origin of the general equilibrium principle and the idea of perfectness one should be aware that in the time when Adam Smith worked on his principles of economics in the second half the 18th century, in natural science the idea of harmony hidden as a godly secret was common in science of its time. Astronomers like Nicolas Kopernicus (1473 - 1543), Galileo Galilei (1564 - 1642), Johannes Kepler (1571 - 1630) and Isaac Newton $(1643$ - 1727) had shown that with the heliocentric cosmology fundamental general laws of simplicity seemingly govern the planetary movements following the law of gravity. Revealing these intrinsic harmonies of the world was extended to other more mystic theological interpretations. This idea of a harmonious world dates even back to Greek philosophers like Phytagoras. The invisible hand Smith invented to explain the hidden harmony behind the chaotic surface of everyday market processes is just an extension of this kind of thinking.

Additionally Gottfried Wilhelm Leibniz, the famous German Mathematician and philosopher, expressed the belief that using differential calculus the future of the world is totally determined by a set of differential equations. He summarized his fundamental beliefs about the state of the world by the following seven principles:

- Identity of indiscernibles. Two things are identical if and only if they share the same and only the same properties. Frequently invoked in modern logic and philosophy. The "identity of indiscernibles" is often referred to as Leibniz's Law. It has attracted the most controversy and criticism, especially from corpuscular philosophy and quantum mechanics.

- $\quad$ Sufficient reason. "There must be a sufficient reason [often known only to God] for anything to exist, for any event to occur, for any truth to obtain."

- $\quad$ Pre-established harmony. "[T]he appropriate nature of each substance brings it about that what happens to one corresponds to what happens to all the others, without, however, their acting upon one another directly." (Discourse on Metaphysics, XIV) A dropped glass 
shatters because it "knows" it has hit the ground, and not because the impact with the ground "compels" the glass to split.

- Continuity. Natura non saltum facit. A mathematical analog to this principle would proceed as follows: if a function describes a transformation of something to which continuity applies, then its domain and range are both dense sets.

- $\quad$ Optimism. "God assuredly always chooses the best.

- $\quad$ Plenitude. "Leibniz believed that the best of all possible worlds would actualize every genuine possibility, and argued that this best of all possible worlds will contain all possibilities, with our finite experience of eternity giving no reason to dispute nature's perfection."

Following this line of thought economics just applies these to the system of markets. Even Albert Einstein expressed skepticism against the new discipline of quantum mechanics built on plenty of violations of Leibnitz principles that god does not play dice. For many scientists it is inconceivable that we live in an imperfect world where a high degree of arbitrariness and indeterminacy rules. Market system has to be perfect at least in principle. Any economic theory violating this belief is a violation of the principle of good science. Market failure is therefore for most economists until nowadays not intrinsic, but caused by external intervention from outside.

In astronomy and cosmology the belief that there is a cosmos governed by eternal laws has crumbled under the empirical evidence collected over the past two centuries. So nowadays cosmologists like Stephen Hawking claim that god must have played dice. The probabilistic nature of the universe, the uncertainty principle in quantum physics and Gödel's proof (Gödel 1931) that mathematical deductions cannot generally be decidable have changed the principles of good science quite a bit from those of Leibniz. However, it took and still takes the economics profession much pain to accept the imperfection of market systems. While perfect planning was ruled out as impossible for a whole economy, the capability of the market mechanism to deal with the coordination problems by the price mechanism as defended against all kinds of empirical refutations. The problem of intrinsic fallibility of free markets is up to now beyond the willingness to accept such possibility as a starting point for economic analysis. The painstaking efforts of theoretical mathematical economists to root out contradictions of their mathematical models about the perfect market system, however, ended all to often in dead ends where an axiomatic formulation of the market mechanism cannot be completely justified on the basis of pure mathematical logic. 
Therefore it is not surprising that the pure logic approach has now more and more replaced by the empirical evidence based approach of experimental economics (see e.g. Smith 1976). If pure logic is insufficient to give truth about the human market behavior than only market experiments to test human behavior might get better insight into the problem of market behavior and dynamics. The problem with this research agenda is that it delivers much more counter evidence against the traditional efficient market model that it becomes difficult to derive a general model of human behavior opposite a market mechanism. Even if a human behavior is reproducible, i.e. by changing the individual participants of the experiment without getting significantly deviating results, the expected common behavior is not easily transferable to the uncontrolled environment of real market not the laboratory experiments. However, this conceptual change in the economics approach might help in the future to get more appropriate assumptions for economics as an empirical founded theory with the potential to derive from these results predictions with a higher degree of reliability. Not market optimism à la Leibniz should rule economics as a science but reproducible evidence from repeatable experiments.

Allowing for all kind of market imperfections helps us to better understand the current financial market failures. To control unfettered markets so that booms and busts are less likely and less severe would be a major progress for the future of our financial market system. If money illusion just is a catch phrase for the inability of market participants to derive from financial market prices the necessary information to make sustainably consistent decision about the future, than one should not expect that financial markets could be efficient and perfect mechanism. Instead one would like Minsky suggested better hedge against such imperfections and failures to avoid the dramatic fall out, when a crisis happens. Imperfect financial markets need built in shock absorbers. Without such built-in stabilizers the economic system as whole is at risk. It is a long way from the belief in a perfect harmonious economic system towards one with significant imperfection and instabilities as an alternative research agenda in economics. 


\section{The problem of cheating in economics}

Intentions of all individual market participants to cheat about the correct pricing are excluded from the analytical framework of academic economic analysis. Because by assumption every market participant is as clever as any other the ability to successfully cheat - at least in the long-run - is controlled by the competitive mechanism. Those who are discovered as cheating will be punished by being stigmatized by the other market participants. Reputation of an honest business person is therefore always considered as something like an intangible asset.

This symmetry assumption of reciprocity in behavioural possibilities is justified by the postulate of equal rights enshrined in the sovereignty of consumers and producers to act independently and on a level playing field. Individual freedom is represented by freedom of individual choice without taking disabilities in the knowledge and capabilities to act of real world people into account. What psychology knows as a fundamental property that people are different in their capabilities as a matter of fact is simply ignored by academic economists as a relevant factor to be considered in economic theories. Market failure in this sense - legal contracts based on misconceptions about the promised services and goods - is therefore beyond the scope of academic economic theory. This might be a severe short-coming in Western economic theory, because wisdom in the Chinese sense of embodying strategems (see e.g. von Senger 1993), i.e. cunningness, in human behavior play a central role in successful business plans. It is also present in everyday business practice but not a subject in theoretical analysis.

Cheating customers, business partners and employees of the implications of their contracts is common practice at the real market place - one example is the Enron case ${ }^{2}-$, but it has no place in economic theory. Discovering the intentions of human behaviour is reduced to a simple nominalism. What people express as their intention is their true intention. There is no possible hidden agenda. The same nominalism is found in the theory of money values which excludes money illusion. However, in particular accounting is a crucial element to give

\footnotetext{
${ }^{2}$ Enron Corporation was an American energy company. Before its bankruptcy in late 2001, Enron employed approximately 22,000 staff and was one of the world's leading electricity, natural gas, communications and pulp and paper companies, with claimed revenues of nearly $\$ 101$ billion in 2000. Fortune named Enron "America's Most Innovative Company" for six consecutive years. At the end of 2001 it was revealed that its reported financial condition was sustained substantially by institutionalized, systematic, and creatively planned accounting fraud, known as the "Enron scandal". Enron has since become a popular symbol of wilful corporate fraud and corruption. The scandal also brought into questions the accounting practices and activities of many corporations throughout the United States and was a factor in the creation of the Sarbanes-Oxley Act of 2002. The scandal also affected the wider business world by causing the dissolution of the Arthur Andersen accounting firm.
} 
transparency about the state of a business company. Bad accounting practices with the intention to hide bad assets and related losses from the public viewing are an essential element in the process of creating money illusion. Off-balance sheet operations is particular harmful because it hides risks for a company to its shareholders. The current banking crisis is not understandable if one neglects these methods of transferring dubious financial operations into special purpose vehicles (SPVs), conduits etc. (see e.g. Roubini, Mihm 2010). A shadow banking system which rapidly grew to a size endangering the whole financial services industry and evading supervision of regulatory authorities have become integral elements of the current financial industry and there is no end to this perceivable. But creative accounting practices have always been an origin of financial market crisis when they become known to the public and cause a crisis of confidence into single institutes or even in the whole industry. Money illusion of the public is therefore closely linked to the possibility of avoid transparency with regard to its shareholders, the regulators and the public in general.

To reveal methods for discovering inconsistencies in the financial accounts of companies will be increasingly in high demand. Sometimes simple heuristics about fundamental relations help to understand or reveal dubious financial statements and discover fraud (see e.g. Gigerenzer, Todd 1999). Offering free lunches or extraordinary high returns on investments are always warning signs that the is a possibility of fraud related to this. So common sense often might help to avoid to be lured into a Ponzi scheme by cunning business people. One potential heuristic that makes us smart would be somewhat paradoxical to take the EMH as a benchmark. The theory states that there is no arbitrage possibility if financial markets are efficient. If rates of returns are higher in one investment than in another that could be only the result of different risk premiums, i.e. higher returns imply higher implicit risks of failure. Therefore risk-averse investors should choose assets taking into account the different riskpremiums. This should raise suspicion about the hidden agenda are cheats which are tempting people to buy a safe assets with exceptional high returns. From the perspective of EMH therefore someone who promises exceptional high riskless profits is something impossible. To believe in these financial miracles is part of the overconfidence of many market participants that they consider they could outsmart the market, i.e. they have deeper insights than the ordinary market participants. That this is an ability not the norm but a rare exception is obvious. Furthermore many people always neglect that insider trading is much more often together with market maker capabilities the origin that constitute the basis for exceptional high profits from single investments. (see e.g. Malkiel 1996). 
A good example is the Goldman Sachs/John Paulson fraud case. Goldman Sachs, the largest Wall Street investment bank, sold a securitized asset, Abacus. What they did not tell the public, was that Paulson's company was involved of selecting the assets which later on was securitized under the Abacus mortgage backed security (MBS). Because Paulson knew about the internal weaknesses of the underlying assets, Paulson's company later on bet on the default of the MBS-fund huge amounts against using credit default securities (CDS) in the derivative market, causing in a sense a self-fulfilling prophecy. Those institutional investors like Industrie Kredit Bank (IKB) in Germany and Royal Bank of Scotland (RBS) in the UK had to face dramatic losses. Goldman Sachs paid in a legal deal with the Security and Exchange Commission (SEC) 550 million US-Dollars to avoid a further investigation and prosecution in an official court case. IKB and RBS defaulted during the last global financial market turmoil and had to be saved by their respective governments.

Similarly the hedge fund investors Raj Rajaratnam (Van Voris 2010) and Sir Allen Stanford (Watts 2009) were taken into remand by the FBI in June 2009 and October 2009 respectively because both are accused of massive insider trading and fraud charges by the SEC. The court cases against Raj Rajaratnam and Sir Allen Stanford on similar fraud charges are still pending. Both examples illustrate that tacit knowledge about companies and their future strategies or the underlying valuation problems of securized assets are sometimes an essential ingredient for huge profits earned in financial market speculation.

Cheating about the willingness to repay debt, untrue promises about the potential returns of an investment, cooking the books in the accounting system, etc. are all empirical valid observations about human behavior in economic environments, but they have no place in economic theory. Such behaviour is considered irrelevant in economic theory construction. They are therefore simply ruled out by assumption.

It took quite a while to make the study of imperfect markets a topic of the profession (see Robinson 1933; Chamberlain 1933) with the exception of the pure monopoly studied by Cournot (1838) and Bertrand (1883). Unfair price setting behaviour expressed through market power of suppliers which significantly deviate from the perfect competitive equilibrium prices which assume that prices are determined by the equality to the marginal cost of production have a role in the area of industrial economics (see e.g. Tirole 1988), but has always been considered as the exception from the rule of perfect competition. The oligopoly problem ${ }^{3}$, i.e.

\footnotetext{
${ }^{3}$ In Economics, an oligopoly is a market form in which a market or industry is dominated by a small number of sellers (oligopolists). Because there are few sellers, each oligopolist is likely to be aware of the actions of the others. The decisions of one firm influence, and are influenced by, the decisions of other firms. Strategic
} 
the way a small number of suppliers establish a market equilibrium is still an unsolved topic in economic since than. There is no oligopolistic equilibrium which is a welfare optimum for a society. Due to scale and scope effects leading to economic of scale size of companies matter (Chandler 2004). This contributes to a higher market concentration in numerous markets. Furthermore network effects (see e.g. Farrell, Klemperer 2007) additionally support higher market concentration and a risk of diminished competition.

However, as part of competition policy the degree of imperfection is always still measured by the benchmark of the perfect market equilibrium, i.e. the respective perfect equilibrium prices. Again there is a wide gap between a competition policy based on the orientation on perfect markets on the one hand and on the reality of competition policy on the other. On the latter pragmatism rules often derived from the legal profession and much less from economic theory. Any attempt to establish economic theories of perfect markets as the principle of legal decisions in competition law suits have been rejected or been unsuccessful when tried out in some exemplary cases.

The legal profession which have to deal with issues of civil and public crimes, i.e. violation of laws, on a daily basis are much more familiar and willing to address this issue as cheating, rip-offs, swindle, etc. which is totally neglected in academic economic research. Deviant economic behaviour like those of Ponzi schemes ${ }^{4}$ practised people like Bernard Madoff $\mathrm{f}^{5}$ are considered just as freaks of the system not the common everyday species we face in everyday day life in the economic sphere. They have to be considered a significant part of human nature in economic theory as well.

planning by oligopolists needs to take into account the likely responses of the other market participants. This makes the fable of the invisible hand à la Adam Smith unconvincing. Coordination of few sellers in a market usually is only successful if it collectively puts the buyers at a disadvantage and the profits earned are share in a way which all side of the seller's cartel accept as fair. This is hard to accomplish and price fixing is illegal due to anti-trust laws.

${ }^{4}$ A Ponzi scheme is a fraudulent investment operation that pays returns to separate investors from their own money or money paid by subsequent investors, rather than from any actual profit earned. The Ponzi scheme usually entices new investors by offering returns other investments cannot guarantee, in the form of short-term returns that are either abnormally high or unusually consistent. The perpetuation of the returns that a Ponzi scheme advertises and pays requires an ever-increasing flow of money from investors to keep the scheme going. It is one potential origin for an investment bubble where asymmetric information between creditors and the debtor who set-up the Ponzi scheme attract a cumulative number of investors who believe in the validity of the business model of exceptional high returns. However, this promise is impossible to fulfil so that at some time the payout of the revenues to the investors collapse. When the investors discover that they are cheated its often to late to recover the money in invested in this kind of business. There is ample evidence that again and again Ponzi-schemes have been successfully implemented at a large scale at different times and countries causing major financial market crisis if the financial system was severely damaged (see e.g. Kindleberger 1978, Roubine, Mihm 2010).

${ }^{5}$ Bernard Lawrence "Bernie" Madoff is an American former stock broker, investment adviser, non-executive chairman of the NASDAQ stock market, and the admitted operator of what has been described as the largest Ponzi scheme in history. 
At the macroeconomic level the belief in EMH has also as a consequence that by this implicitly the existence of financial market bubbles is ruled out. Because of that most academic professionals in financial market analysis have very little to say if they are facing the phenomenon of financial market bubbles (see e.g. Roubini, Mihm 2010). Contrary to those who disbelieve the EMH - like economists like Minsky $(1982,2008)$ who has early on pointed out that financial markets in particular have an inherent tendency of instability leading to recurrent financial markets crisis - the pre-dominant mainstreams at academia rejects this instability of financial market hypothesis (IMH.)

Tricks and cheats used by economic agents in the everyday market process are from the perspective of most academic theorists just noise and a veil created to fail to discover the fundamental laws of market systems. This kind of framing however is misleading theoretical analysis by leaving key elements of financial market failure out of sight. So it is common practice not to study any kind of deviant economic behavior as a research topic in economics. However, the impact such deviant behaviour even can cause on the macro level of whole economies or even the global economy is too important to be ignored as an ancillary factor in the whole economic system. The selection bias to focus on behaviour which guarantees market efficiency outcomes leads to severe problems to assess and predict real world market events governed by booms and busts. What Minsky was well aware of, is that fraud and cheating is common practice in a market economy. If regulatory oversight is to negligent or even regulatory capture takes hold in the supervisory institutions the incentive to create high personal income through financial market manipulation takes overhand. So contrary to the free marketers or radical market liberals Minsky suggested a strict system of effective oversight and rules which makes these kinds of activities at least more risky if not impossible. To have more efficient financial markets one has to accept that inherent inefficiency of selfgoverning markets. This kind of perception of Minsky is also more in line with actual economic theories of crime (see e.g. Eide, Rubin and Shepherd 2006). If human nature is to a large extent driven by greed to get rich, than it needs a Leviathan to keep this greediness under control especially in financial markets. One central element of a governance structure has to be proper accounting rules and transparency of financial markets. Furthermore it needs credible punishments for violating the regulations of good financial market governance. Crime without punishment to deter misbehaviour is an essential element of the economic of crime analysis.

In this sense economic theory based on the EMH is a Neo-Platonic philosophy where the pure idea about markets should not be spoiled by the impure evidence in the real world of market 
processes. The market ideal is the essence or true nature of all observable empirical markets. Those who fail to see the beauty of the essence of the market system are just ignorant and infidel about the fundamental truth about a market economy. They are puzzled by the surface of everyday market events with all kinds of imperfections and ignorant about the essence of the market process, the ideal market system. This dogmatism resists any kind of open debate according to counterfactual evidence.

\section{Human behaviour in economic interactions}

The further fundamental fallacy in the theory of individual economic behaviour rests on the assumption that it is restricted to simple behavioural rules of a market exchange game. This makes the analytical treatment easier, but excludes many behavioural possibilities which are common to human practice.

Standard economic theory is based on maximising or minimising continuous differentiable functions under constrains, e.g. utility, cost or profits. It neglects information uncertainty problems associated with the functional structure and parameterisation. Instead of using at least probabilistic distributions to catch the uncertainty about the state of an economic system one reduces this problem via the certainty-equivalence-principle (CEP) by using rational expectations as a sufficient indicator for economic analysis and reduces the randomness of economic processes to a simple error or noise process. Under the CEP the traditional analytical results are easily transferred beyond their traditional framework of deterministic analysis using the classical calculus as its analytical instrument together with the expectation value operator.

What often is designed in the Marshallian tradition of partial analysis (Marshall 1890) is extended as well into the general equilibrium analysis which deals with a simultaneous multimarket equilibrium in the tradition of Léon Walras (Walras 1874). However, this raises the problem of multiple-equilibria which was ruled out for quite some time as inadequate in theoretical economic analysis until it finally get its academic acceptance in the economic literature (see e.g. Diamond 1987). This is another challenge of indeterminacy of an economic system. Before the general equilibrium literature was obsessed to establish conditions of a unique general equilibrium. Multiple equilibria were considered degenerated cases where artificial restrictions imposed on the market system led to such perverse results. The political treatment is to remove the unwarranted restrictions and the unique and perfect general equilibrium prevails. Again it was a major financial market crisis in the emerging economies which stimulated research on the possibility of multiple-equilibria (see e.g. Masson 2001). It 
seems crisis in economic reality is always a good teacher to dismiss long hold prejudices enshrined into axioms used in economic theory. If the dominant theory fails to explain and predict a current economic event the willingness to accept more "exotic" theory elements increases significantly. The unpredicted real world crisis by economic theories induces a reform in the theoretical framework in economic theories, at least sometimes.

In the simplest market clearing bargaining game the assumptions are set in way that only prices or quantities offered matter and a contract has to be done by both parties. In a sequence of bid and rejections of different offers the bargaining process converges towards a bargaining equilibrium a contract where a certain amount at the final bargaining equilibrium price is exchanged. Of cause the logic of such a simple bargaining game is convincing, but it does not ask questions of changing the bargaining framework conditions.

As Akerlof has demonstrated in his market for lemons example (Akerlof 1970) if there is uncertainty on the buyers-side about the quality of the product the seller-buyer-equilibrium will fail to meet the conventional equilibrium price setting rules. So the problem in economic analysis is to define the rules of a game properly to match those of possible human strategic behaviour. If one omits possible actions of an economic agents just to get a simpler and mathematical easier tractable model one runs the high risk to fail human actions because it will extent the rules of the game by changing the rules itself. One stratagem in the lemon market case is the lack of the buyer to know sufficiently well about the quality of the product, e.g. a used car. If the seller is unwilling to reveal his information advantage and there is a lack of trust in the honesty of the salesman, than the bargaining fails even if the simpler standard model of efficient bargaining would predict a successful trade at an equilibrium price.

So the lesson to be learned is that many economic theories are based on assumptions which cannot be matching the real world environment. Reality refutes assumptions in many dimensions to invalidate the theory based predictions. Theories and mathematical models cannot match the real world outcome because they ignore important behavioural possibilities of the respective agents. False prediction of behaviour is the outcome of false and too narrow restrictions about the possible human behavioural space. If one bases its predictions on the validity of fair play rules ignoring the willingness of agents to break these rules when they perceive a potential benefit from it, theoretical predictions become invalid.

So the thorough explicit listing on the assumptions necessary to obtain analytical results should be an essential ingredient for academic scientific research in economics, but this is far less common practice as one should expect. Often essential restricting axioms are not revealed 
with the intention to give the theory the impression of a high degree of generality which for the well trained academic economist if obviously not the case. Limited validity of a theory together with seemingly generality communicated to the less well trained public often severely bias decisions in favour towards a theoretical model which cannot stand the test of reality. What we need in economics are realistic assumptions about human behaviour to derive realistic conclusions.

Academic economists often cheat willingly the general public about their general understanding of economic phenomena under investigation. Because of their reputation as scientists who are experts to know much more than the general public they simply impose their prejudices based on imperfect models and analysis in the general political debate. Everybody knows about the willingness to cheat to obtain desired results from early childhood on. However, when we deal with economics as a theoretical discipline we simply ignore this important dimension of human behaviour. Another possibility is wishful thinking to construct a logical deduction omitting important alternatives from our decision tree.

A good example is the stagflation phenomenon. Until it emerged after the two oil price shocks in the late 1970s and 1980s, no economist trained in the Phillips-curve (Phillips 1958) would have considered the simultaneous coexistence of high inflation with persistent output recession or at least stagnation as possible. Reality told academic economists a lesson about possibilities of economic development which lay beyond their imagination based on a tradeoff between unemployment and inflation. After the world economy recovered from stagflation the interest in studying the subject in academia veined and might probably become a hot topic in the near future because the current global recession policies of easy monetary and unsustainable fiscal policies are insufficient to establish a sustainable economic recovery.

If the reality refutes the predicted outcome there are a lot of ways to justify why one - the expert - could not know about certain circumstances enough to give a policy recommendation which results in the predicted outcome. We failed because we had in information problem, is s stratagem to justify ones failure. Insufficient consideration of potential outcomes is one key element in the self-excuse stratagems.

\section{(include the queen Elizabeth debate in Britain here)}

"We could not know that this could happen because it never happened before," is one way to excuse the inability to give reliable predictions.

"Something or someone has broken the rules of the game" is another way to justify failure to predict successfully the outcome by the academic profession in economics. 
Taking the current global financial market crisis gives lots of examples for explaining away the failure to assess and predict the current catastrophic outcome.

\section{Financial Markets, the Future and Uncertainty}

In the simple illustration of general equilibrium or partial equilibrium models the efficient market equilibrium is simply determined as if only the present demand and supply matter. However, every economist would easily accept that this is a major oversimplification about the economic problem of production, allocation and consumption of goods and services using money as medium of exchange. It is the future that matters and the expectation about the future development is essential for what is going to happen on spot markets today. Without taking this interconnectedness between present and future into account most of the analytical results based on a pure spot market mechanism will fail.

However, one fundamental problem about the future is that it is more or less uncertain. Frank H. Knight (1921) was right when he clearly separated the problem of uncertainty from risk. Uncertainty includes not a randomness of events which can be represented by a random variable with a specific probability distribution but embodies the model uncertainty about the probability distribution itself. Classical parametric statistical methods however are based on the necessity that the underlying probability distribution is known and use estimation functions to determine the respective parameters to be able to make inferences about the riskiness of possible future events. Some well trained econometrician will claim that on the one hand the central limit theorem of inference ${ }^{6}$ helps to avoid the exact knowledge the exact probability distribution because at least asymptotically the distribution of the expectation value converges against the normal distribution. If the random sample of a particular economic random variable is sufficiently large enough and the single observations are identically and independently distributed the particular distribution function does not matter if one wants to draw only inferences about the expectation value of the random variable. Furthermore one can use non-parametric methods of inferences (see e.g. Hettmansprenger, McKean 1998). But this does not change the underlying fundamental problem that observations should be obtained from the same underlying distribution and that the single observations are independently distributed from each other. If the underlying distribution function constantly changes over time one has at least to make assumption about this

\footnotetext{
${ }^{6}$ In probability theory, the central limit theorem (CLT) states conditions under which the mean of a sufficiently large number of independent random variables, each with finite mean and variance, will be approximately normally distributed.
} 
dependency structure before one can draw conclusions using estimation functions about the future outcome in particular of the expectation values. Not knowing about the changing risk interdependencies of financial assets in securitized papers was one cause why the whole securitized asset market finally collapsed. If the default of one real estate has significant impacts on another and this causes a contagion process, the simple independency assumption underlying the securitization models about the risk structure fails.

In economics one has become well aware that there exists a problem of path-dependency ${ }^{7}$ in economic development (see e.g. Arthur 1994). Since the current state of a society is the result of past decisions the current state depends on a sequence of past choices so that the present state is not independent from the past or as a catch phrase says: history matters. But not only the past matters but the future expectation about future trends and developments matter as well. In particular in the area of investments into any kind of asset the expected rate of return is essential for the valuation of the respective asset. Present values are always calculated by using the expected rate of return to discount the future income stream of the asset. Since the expected rate of return is more or less uncertain the problem of uncertainty enters the market mechanism via this channel. Furthermore the discounting of future income streams of an asset causes a significant compound interest effect which becomes increasing dominant with the length of the respective time horizon of the asset under consideration. On top of this there is empirical evidence that humans tend to deviate from the standard discounting procedure and follow more a hyperbolic discounting approach (Thaler 1961, Aisnlie 1975). This, however, leads to time inconsistent decision making.

The information problem some one has to solve under such circumstances is tremendous. To get a reasonable outcome one has to know the complete income stream in advance together with the correct expected rate of return and take into account that the realisation of all this variables faces some degree of uncertainty in its realisation. If the predictions are incorrect the market mechanism has to adjust for this miscalculation. The larger the bias forecast has been the more dramatic the adjustment which after a certain threshold level might be considered an adjustment shock. If major unpredicted events in the near future or perceptions about future developments afterwards happen, this has significant consequences on the present value of the respective asset. This makes asset markets much more fragile with regard to the volatility of the asset prices than ordinary commodity markets. Since investments into a real asset like a

\footnotetext{
${ }^{7}$ Path dependency explains how the set of decisions one faces for any given circumstance is limited by the decisions one has made in the past, even though past circumstances may no longer be relevant.
} 
machine or real estate also has as a consequence a lock-in effect, it cannot be converted to another form into a liquid assets or only at significant costs, this makes those markets most vulnerable to revaluation problems. The new financial innovation of asset backed securities just created easy liquidity without risk to assets which a re intrinsically illiquid. The intrinsic riskiness of the underlying assets like real estate or entitlements on the future income stream of debtors like households, however, face the revaluation problem under uncertainty depending on conditions of the overall economy not under the individual control of the people who sign the contracts.

This problem becomes even more significant if we take into account the Schumpeterian view (Schumpeter 1911) that economic development is a process of creative destruction through innovations. Since the predictability of innovations is highly limited, any major innovation, i.e. a general purpose innovation (GPI $)^{8}$, causes major revaluation shocks in the asset markets. Therefore it is no accident that innovations like the rapid developments in ICTs and in particular of the internet with its network effects or the innovation of securitization as a mean to distribute risk have become a source of huge volatility in the associated asset prices in particular and changed the economic growth and income expectations of the whole global society. If the visionary expectations would have been correct the social income stream of the future would have increased dramatically (see e.g. Jorgenson, Stiroh 2000).

At the centre is always an event which is a certain type of innovation. The general public starts to speculate about the high positive impacts this innovation, e.g. a discovery of a new continent like the South Sea, a new general purpose technology (see e.g. Helpman 1998) like the Internet or securitization as mean to disperse risk and those involved in this type of activities start to act as visionaries who promise extremely high revenues from this new kind of activities. Since they often lack the money to finance endeavours to internalise the perceived high profits exclusively they offer others the one time opportunity to participate and earn a significant share of the high profits. People who otherwise have to work hard to make their money become attracted by such easy to get rich opportunity and often use large amounts of their savings to spend them on the seemingly safe bet of some investors. They highly advertise their too good to be missed opportunity. If they are crooks they take a hit and run stratagem to flee with all the money the got before the stupid financiers discover the

\footnotetext{
${ }^{8}$ I prefer the term general purpose innovation instead of general purpose technology because it includes all kind of major innovations which not necessarily have to be technology based. Securitization is not a technological innovation in the narrow sense, but it had a dramatic impact on the financial market system and by this on the economic as a whole.
} 
fraud. Sometimes it might even happen that the one that runs the doomed business is so much convinced about its success that they become their own victim. Ventura capital financing is all about this problem. After all the perspective to get effortless rich is a common feature of all major scams. Money lies around and you only have to pick it up. This mirage of financial market prophets is a key driver for building-up communities of believers which create a financial market bubble. The symptoms of this kind of irrational exuberance are well known (see e.g. Kindleberger 1978, Greenspan 1996, Shiller 2000).

However, it has become a stratagem for policy makers responsible for financial market supervision to claim that financial market bubbles are unpredictable. There might be some truth to it, if one expects unconditional prediction which matches the real outcome perfectly. Of cause there is intrinsic uncertainty about the future, so that it is impossible to make the claim that the nearer or further off future the state of an economy might be predicted with certainty.

Afterall, there are often indications which make the claim that there is a financial market bubble emerging which are reasonably safe to take early action on (see e.g. Shiller 2000, Roubini, Mihm 2010, Chap 1 \& 2.). People who have kept their animal spirits alive know that certain financial market trends are unsustainable and a correction to break an unsustainable trend is needed. But there is a difficulty to give an exact plan how and by how much policy intervention are bubble can be deflated in a way to assure a soft landing.

Even more so it is too much to expect a perfect bubble deflation policy based on a perfect model about the financial market bubble currently emerging. It this simply this overblown expectation at policy makers to justify their policy actions that leads to a laissez-faire attitude in the end. One refrains from doing something because one fears the blame game when market participants will proclaim that this action was unnecessary and harmful.

Those who are making a fortune as long as the bubble expands will always be those who can't see the dark clouds on the horizon emerging. As long as the party is rolling they say they just have to be opportunistic because otherwise their shareholders would make them responsible for lost incomes if their prediction were wrong. This kind of harmful herding behaviour creates a kind of vicious circle of ruthlessness even if one already knows that things will collapse sooner or later. Pre-emptive bubble pricking is therefore something monetary policy makers have declared as a taboo on their policy agenda. John Paulson and many other 
speculators are less scrupulous when they learn about an unsustainable financial position, see .e.g. the recent Greek sovereign default crisis.

Facing the dilemma of too early too much opposite too later too little, those responsible for financial market supervision have decided for the second option. Pre-emptive bubble pricking is still a taboo. This end-of-pipe attitude - first let the bubble burst and than fix the failing system again - might be the worst choice taking the opportunity costs of both strategies into account. This is a harmful attitude which cost the society dearly in the end as the enormous amounts of tax payer's money spent for bailouts illustrate.

Probably the truth lies between the two extremes of the white (Roubine, Mihm 2010) and black swan. (Taleb 2007). Our knowledge about emerging bubbles is sufficiently large enough to know that it is a light grey swan and the longer the bubble grows the darker the grey swan becomes until it is pitch black.

\section{Uncertain future developments, false predictions and cheap talk}

As we have seen in the previous two sections future developments affecting market valuations embody a prediction error problem plus the possibility of cheating about the seriousness of the predictions presented to the public. This creates an identification problem. Can you trust the predictions made by some business people or political institutions that are stakeholders in the respective businesses or have for the latter a hidden agenda for example re-election?

In economics one is aware of the possibility of cheap talk (see e.g. Farell, Rabin 1996, Crawford, Sobel 1982) as a means of signalling something different than the actual wording given in the statement himself. Furthermore as false prophets often do the predictions are sufficiently vague to give room for interpretation. Talk of politicians addressing the public often intentionally gives only highly imperfect predictions but in a way that their constituency fill in the information gaps with their own hopes and aspirations. The audience reads between the lines by confabulation what the wish to hear. So the dissemination of information through the media might be highly biased in many respects. Newspapers and news services are often as well not impartial in the presentation of information (see e.g. Herman, Chomsky 1988).

Therefore the issue of credibility of information is another critical issue in the valuation problems of markets. Since financial markets are heavily dependent on information in particular about the future, i.e. prediction markets, the constant stream of contradictory 
information spread needs a high capability to filter relevant from irrelevant or false information and propaganda. Since the ancient Greek philosophy the art of rhetoric ${ }^{9}$ has been in high esteem. A well trained speaker in rhetoric could accomplish to convince a greater audience with his arguments even if they are misleading from the rational choice principles. Sophism $^{10}$ - in the interpretation of Plato - has become a way still nowadays to influence peoples thinking not to help them understand the real state but instead to trick them into common fallacies for a specific advantage. Often in financial markets sophists tend to convince people by their cunning rhetoric into to their faulty businesses. This phenomenon of mass psychology contributes significantly for developments in financial markets crisis und financial bubbles. Ponzi schemes tend to use those peoples with this special talent again and again. This however shows exemplary that the symmetry assumption about ability to make rational choices differ in the population. The smart guys trick the stupid ones often using again and again the same tricks.

The same is sometimes true for economic policies. Theories are invented out of the blue to justify irresponsible economic policies. A good example is the Laffer curve ${ }^{11}$, which state that tax income losses to the government by lowering tax rates would be overcompensated by the increase in taxation due to higher taxable private incomes. This spontaneous suggestion about the working of an economy became a lynch pin of the Reaganomics policy of the 1980s. Later on the budget director, David Stockman (Stockman 1988), called this approach Vodoo Economics. This insider-outsider-problem of those who know that what they are doing is pure propaganda for a false policy design is another essential element for misguiding public policy opinion by experts who know better. Stockman disbelieved the strategy of the Reagan administration but as long as in office he used his rhetoric capabilities to convince the public that it might work wonders. It didn't as we now know, but at the time being it worked to cheat

\footnotetext{
${ }^{9}$ Rhetoric is the art of using language to communicate effectively. It involves three audience appeals: logos, pathos, and ethos, as well as the five canons of rhetoric: invention or discovery, arrangement, style, memory, and delivery.

${ }^{10}$ Sophism can mean two very different things: In the modern definition (from Plato), a sophism is a specious argument used for deceiving someone. In Ancient Greece, the sophists were a category of teachers who specialized in using the tools of philosophy and rhetoric for the purpose of teaching aretê — excellence, or virtue — predominately to young statesmen and nobility.

${ }^{11}$ The story of how the Laffer curve got its name begins with a 1978 article by Jude Wanniski in The Public Interest entitled, "Taxes, Revenues, and the 'Laffer Curve."'1 As recounted by Wanniski (associate editor of The Wall Street Journal at the time), in December 1974, he had dinner with me (G.E. Arthur Laffer then professor at the University of Chicago), Donald Rumsfeld (Chief of Staff to President Gerald Ford), and Dick Cheney (Rumsfeld's deputy and my former classmate at Yale) at the Two Continents Restaurant at the Washington Hotel in Washington, D.C. While discussing President Ford's "WIN" (Whip Inflation Now) proposal for tax increases, I supposedly grabbed my napkin and a pen and sketched a curve on the napkin illustrating the trade-off between tax rates and tax revenues. Wanniski named the trade-off "The Laffer Curve."

see http://www.heritage.org/Research/Reports/2004/06/The-Laffer-Curve-Past-Present-and-Future
} 
the public. The current unsustainable public deficit position of the US government just continues the bad fiscal policies of the US governments of the past 30 years (see e.g. Erber, Weber, Rudoph 2009). There can be no doubt about the fiscal unsustainability of the US federal budget planning for the coming years.

If the general public gets increasingly doubtful that previously believed prediction or scenarios about future developments are still valid, this could cause an information cascade of revaluations ${ }^{12}$. These reflect themselves in the financial market prices often quite dramatically. The financial market panics observed when a bubble bursts is just this kind of contagion effect created by the spread of new true or false information. This changes the valuation of assets accordingly.

\section{Fiat money and seignorage}

Fiat money has different meanings. It is any money declared by a government to be legal tender, but since there is no intrinsic value associated to it anymore it can be created without any real valued assets like gold or silver in the past. ${ }^{13}$ Therefore it even does not need a creation of money by the printing bank notes or coins to circulate as means of payment. It is just sufficient that the central bank decides to accept other assets in exchange for offering a virtual amount of legal tender on the central bank account. A commercial bank exchanges other assets which lack this legal tender property with the central bank and obtain central bank money instead. This they can use than to make any payments to other customers. Similarly a government can swap government bonds in exchange for fiat money of the central bank. Since the central bank by issuing fiat money has in principle an obligation opposite the holder of such money it has to take care to be able to offer the holder of fiat money another asset in exchange on demand. However, the value of the fiat money is unfixed with respect to the potential assets. Money illusion emerges simply emerges if people would expect that the value of money is stable, i.e. the purchasing power is not affected in particular by high inflation. By keeping inflation under control the fiat money is accepted as a reasonable store of value. A central bank losing their credibility for keeping inflation under control is putting their fiat money holdings as store of value at risk. This would find its empirical expression in a higher velocity of circulation of fiat money because people dismiss this kind of money as

\footnotetext{
${ }^{12}$ An information (or informational) cascade occurs when people observe the actions of others and then make the same choice that the others have made, independently of their own private information signals. Because it is usually sensible to do what other people are doing, the phenomenon is assumed to be the result of rational choice. Nevertheless, information cascades can sometimes lead to arbitrary or even erroneous decisions. (see e.g. Bikhchandani, Hirshleifer, and Welch 1992).

${ }^{13}$ The Song Dynasty in China was the first to issue true paper money, jiaozi, around the 10th century.
} 
inadequate as a proper store of value. So fiat money has the intrinsic problem that its function as a store of value is only possible if inflation is kept under control. Fiat money has therefore a higher risk to end up in hyperinflations if governments and their central banks use this as a means to fulfill debt obligations to the public (see e.g. Cagan 1956).

If central banks change their commitment on price stability somewhere in the future people will tend to adjust for this loss of functionality by using other assets in exchange for this purpose. So money illusion emerges as a fact in the perception of the public, when the central bank does not uphold their commitment of price stability. Since the information about this policy shift might dissipate unevenly to the public this process will not happen instantaneously. Insiders might adjust more rapidly than outsiders so that distributional effects cannot be ruled out, putting outsiders at a disadvantage.

Since most of the central bank money created is needed by the financial markets fiat money is similar to a permanent loan of the public to the central bank. Because of this limited obligation money creation gives the central bank a surplus which is also called seignorage. Seignorage is the interest earned on the assets acquired in exchange for the fiat money. These revenues are similar to a tax for the supply of liquidity of fiat money paid by the private sector. If bank notes or coins are issued these costs have to be subtracted from the overall seignorage of the central bank for the public. Since the central bank is an institution of the government at least some parts of the seignorage is transferred to the government as transfer payment. Since central banks who buy assets in exchange for paying with fiat money they have to value these assets according to common accounting principle like least value principle as used for foreign currencies or gold to hedge against potential losses and built up reserves in the case there is demand in particular high demand for foreign currencies as has happened during the recent Euro-crisis in 2010. My using mark to market valuation the central bank could face a higher volatility in their assets valuations depending on the market situation for these assets. To constrain these negative effects the central banks like the ECB usually accepted assets with a high triple AAA rating which are considered the most safe assets hedged against high market volatility in their asset prices. However, this behavioral rule has been temporarily abolished during the current global financial crisis putting the balance sheet of central banks at risk to end up with huge losses or even could face insolvency when the central bank assets are devalued that the own capital is not covering the losses of buying bad assets from the commercial banks to stabilize the financial sector.

Up to now this has not endangered the credibility of major central banks of the Fed, ECB, the Bank of England or the Japanese central bank to guarantee price stability; however, this might 
change if governments get more and more highly indebted. Fears of sovereign debt failures are significant triggers for the change of the public perception about the solidity of the respective fiat money issued by the central bank of that country or respective currency union like the Eurozone.

\section{Seignorage under international financial market integration}

In an international financial market integration regime - i.e. under a regime without capital market controls - seignorage incomes not only emerge from the domestic private sector but as well from the foreign countries, if they hold currency reserves of the fiat money of a particular country like the US or the Eurozone as a currency union. These global reserve currencies earn significant benefits from the willingness to hold huge currency reserves of these currencies to hedge against a major currency crisis to avoid insolvency, see e.g. the case recent of Island, where insolvency could only be avoided through financial life lines given by the IMF and foreign governments. The insolvency risk of in particular small countries which lack the ability to finance foreign debt in their own currency denomination includes the currency illusion if a major financial crisis emerges in the international financial markets. Therefore the loss of credibility of a domestic government and its central bank to maintain sufficient price stability tends to drive their population towards other currencies as a more reliable store of value. This kind of Dollarization or Euroization transfers the Seignorage revenues of the countries holding the reserve international currencies to the respective foreign countries in particular the US as the still dominant global reserve currency (see e.g. Feige, Dean 2002).

\section{Figure 1 - Official Global Dollarization and Euroization}

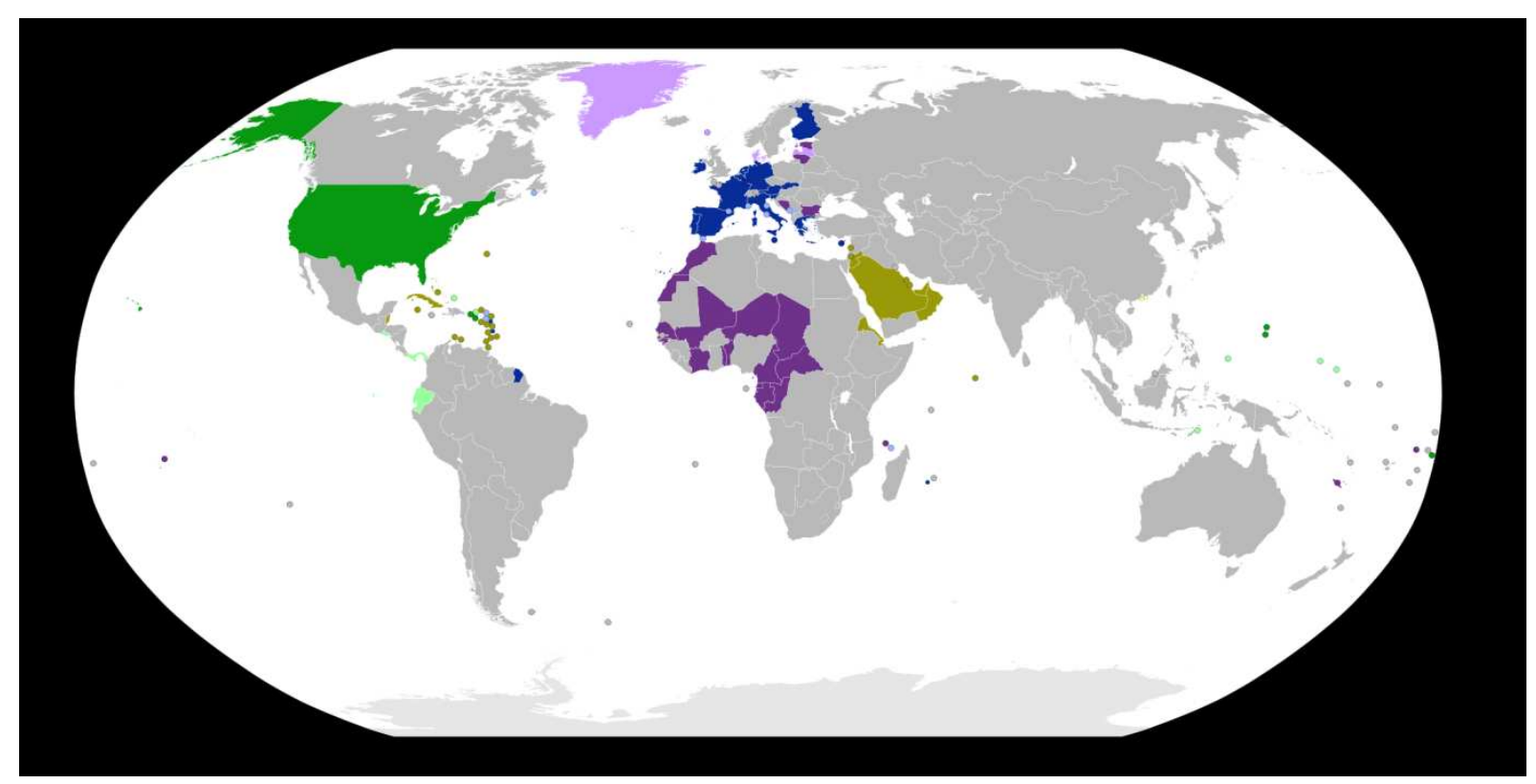

Worldwide use of the U.S. dollar and the euro:

United States 
External adopters of the US dollar

Currencies pegged to the US dollar

Currencies pegged to the US dollar within narrow band

Eurozone

External adopters of the euro

Currencies pegged to the euro

Currencies pegged to the euro within narrow band

The huge amount of dollar exchange reserves accumulated in particular in Asian countries like the PR of China, Japan or oil producing countries like Saudi Arabia over the past decade has become a very expensive hedge against the potential risk of a currency crisis (see table 1 below). These few holders account for more than $60 \%$ of total world foreign currency reserves. The adequacy of the foreign exchange reserves is more often expressed not as an absolute level, but as a percentage of short-term foreign debt, money supply, or average monthly imports.

Table 1 - Major countries official holdings of US-Dollar currency reserves

\begin{tabular}{|c|c|c|c|}
\hline \multirow{2}{*}{$\begin{array}{l}\text { Rank } \\
1\end{array}$} & Country & \multicolumn{2}{|c|}{ Billion USD (end of month) } \\
\hline & People's Republic of China (China) ${ }^{\text {note } 1}$ & June 2010 & $2,454.3$ \\
\hline 2 & - Japan & June 2009 & $1,019.0$ \\
\hline & Eurozone & Oct 2009 & 716.0 \\
\hline 3 & Russia ${ }^{\text {note } 2}$ & Apr 2010 & 456.0 \\
\hline 4 & - Republic of China (Taiwan) & Apr 2010 & 357.6 \\
\hline 5 & India ${ }^{\text {note } 2}$ & Mar 2010 & 277.0 \\
\hline 6 & South Korea & Nov 2009 & 270.9 \\
\hline 7 & † Switzerland ${ }^{\text {note } 3}$ & May 2010 & 262.0 \\
\hline 8 & $\otimes$ Brazil $^{\text {note } 4}$ & Jun 2010 & 253.5 \\
\hline 9 & * Hong Kong & Nov 2009 & 240.0 \\
\hline 10 & Singapore & May 2010 & 203.4 \\
\hline 11 & Germany & Sep 2009 & 184.0 \\
\hline
\end{tabular}

Notes

1. China updates its information quarterly.

2. Russia and India update their information weekly and monthly.

3. Swiss National Bank's currency reserves leapt more than 50 per cent from $\$ 145.6 \mathrm{bn}$ in April to \$261.9bn in May 2010

4. Brazil updates its information daily.

If the US would lose its credibility to maintain monetary stability domestic and even more so foreign currency holders might rush for an exit and by this defuse the currency illusion with regard to exchange rate stability very quickly. Exchange rate volatility is therefore an 
indicator for credibility problems between different countries- Up to now the US-Dollar has profited from such developments as a safe haven for international investors under periods of global financial crisis. If the US-Dollar would lose this extraordinary privilege because of increasing doubt in the solvency of the US-government it could trigger major turbulences in the global financial market system (see e.g. Roubini, Mihm 2010, Chapter 10). Especially after the current global financial market crisis which has had its origin in the securitization of huge amounts of dubious assets like mortgages for subprime customers (see e.g. Shiller 2008), but also in many other areas which heavily used consumer credit later collateralized in CDOs (collateralized debt obligations) as a mean for stimulating and financing an excessive consumer demand (see e.g. Roubini, Mihm 2010, Chap. 4), have created a huge legacy of toxic assets which led to the bailout of major investment and commercial banks in particular in the US and Europe.

Easy credit helped to create money illusion by many debtors that they have not to face a restrictive budget constraint. Rapidly rising housing prices over many years contributed to the belief that in case of financial troubles house owners could easily obtain liquidity from their real estate without facing significant losses. When the housing bubble burst these expectations about a sound financing and manageable risk in case of liquidity problems to pay back mortgages lost its credibility and the investments in private housing ran into bankruptcy due to the contagion effects of fire sales to obtain at least some money back from the real estate under a scenario of rapidly sinking housing prices.

So money illusion has had in this case its origin in asset price inflation triggered by low interest rates. One origin was a loose monetary policy of the Fed in the US which under its previous Chairman Alan Greenspan helped to fight the negative impact of a previously burst new economy bubble. Another was the possibility to use financial innovations created in the investment and commercial banking sector to distribute risks of risky assets around the globe by cheating about this riskiness against the naïve buyers of from rating agencies like Standard \& Poor's, Moody's or Fitch highly rated triple AAA securitized assets like mortgage backed securities (MBOs) about the potential liquidity and valuation risks inherent in these papers. ${ }^{14}$

\footnotetext{
${ }^{14}$ See e.g. the newspaper articles "US credit rating agencies 'a colossal failure' in the Independent from October 23, 2008. The newspaper makes the quotation: "The rating agencies broke this bond of trust, and federal regulators ignored the warning signs and did nothing to protect the public," said Waxman, a California Democrat. "The result is that our entire financial system is now at risk." The statement of the rating agencies when the lawmakers criticised the three largest credit rating agencies for their role in the worst financial crisis in decades, that they claimed they didn't see it coming. Well this might be always true in the sense that people there spend little time to use their imagination to consider stress tests similar to the real events as a realistic assumption for their rating process. Again overconfidence in the stability of the financial markets was an
} 
Above normal market interest rates offerings for these assets attracted private and institutional investors who were blindfolded because they trust the reputation of the issuers of such assets like e.g. Lehman Brothers and the quality of ratings of similarly well established rating agencies. Since there is now lot's of evidence available that insiders of this Ponzi scheme were well aware about the intrinsic vulnerability of the complexity financial products, it is ample proof that moral hazard has been a core element of the market failure in this segment of the financial markets. High bonus payments for sales of such assets for the investment bankers reduced any self-restraint to avoid a disastrous imbalance between the real value and the nominal value of such assets.

\section{Conclusions}

The lesson to be learned is that money illusion has many different causes all associated with the common fact that money as an accounting unit for market values cannot signal the information about the underlying value problems in a proper way. This is contrary to Hayek's belief that market prices are sufficient statistics to convey all necessary information needed to make a decision (Hayek 1945). If the pricing mechanism is flawed because it cannot signal in particular future valuation problem properly, the conversion of all valuations into an accounting unit of fiat money makes thing even worse. The exact numbers tend to mislead economic agents to give them a degree of certainty which cannot stand-up to the riskiness intrinsically embodies in the dynamics of markets where demand and supply driven adjustments are taking place without questioning the efficiency of the market prices as proper instrument to gear the production and allocation of resources.

If false trading is possible then even according to orthodox market liberals misallocation and wrong decision take place. Since this error is not immediately visible to the naïve observer or trader they draw wrong conclusions from the current outcomes. A lucky outcome of a speculation is reinterpreted as deep insight into the function of the economy or specific market trends. The belief to have learned a lesson how to play the markets changes the willingness to take risk because the risk awareness is numbed by the current lucky streak of favourable events. The subjective risk perception deviates more and more from the objective risk associated with the current market trend. Even if early on signs show-up that things could

essential ingredient to avoid a deeper questioning about potential risk scenarios. Putting the benchmark tests low, the models used in securitization did not reveal a significant risk that could make such papers toxic. Complacency based on past successful performances changed to willingness to accept risks into the false direction. Such false conclusions are common in human behavior when expectations about future risk are just based on a short-term of past performances (see e.g. Lowenstein 2000). 
turn into the opposite direction in the near future, people often tend to develop a selective perception about the information available. One is looking for positive evidence that support the current prejudice and less for evidence which would falsify the maintained hypothesis how things are. So many critics of the high-risk and problems already visible in the financial system before the last global financial bubble burst were ignored and talked down (see e.g. Roubini, Mihm 2010, Chap. 1). Contrary to Taleb (2007) who used the catch word black swan to claim that financial crisis are a very rare events, Roubini calls the current financial market crisis a white swan. It has nothing which went beyond common knowledge about how financial market crisis developed in the past. Same, same but different - a Thai saying - could be said about the stylized facts of a major financial market crisis.

What the author hopes to have illustrated by the present paper is that the two extreme beliefs, i.e. that there is a possibility of perfect planning or that there is the possibility of perfect markets to solve the coordination problem of economic activities are definitely wrong. They are both ideological constructs which emerged at a time when socialist and capitalist ideologists fought each other in the past two centuries. Both approaches are highly imperfect because they always have to deal with the uncertainty problem of future developments which are never under the complete control of planners or market participants. Market are therefore more or less second best solutions. Market failures are because of the intrinsic information dilemma with regard to future developments the rule and not the exception. People get it always wrong, they are imperfect in their abilities to process complex information and especially to predict the collective behaviour of societies. Preferences and ideas about the future change constantly. Markets are just institutions which adjust to these constant changes according to the revealed information to the public and its spread to the respective decision makers. Financial markets are the essential lynch pin between the present and the future. Money as a mean to express valuations and as a universal mean to give access to all kinds of assets and resources becomes the focal point were all these imperfections get visible in the market prices. They never represent an equilibrium state to a steady state of the economy.

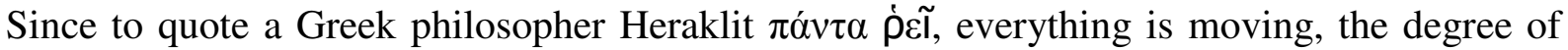
turbulence governing the economic development causes always some degree of mismatch between the real economy and the monetary sphere as its virtual representation of the human valuation of the state of the economic system. A one to one correspondence is impossible to accomplish. 
However, it is at least possible to detect exceptions developments in the financial market valuations of financial assets and ask for their underlying foundations with sustainable economic developments. If there is insufficient support to believe that this valuations make any sense on the long-run, if one detects all kinds of human irrational exuberance in the market place about the future possibilities to earn exceptionally high returns than it should be time to act for those responsible for monetary policy and financial market supervision to counterbalance these developments in a timely manner to keep things under control.

Even if there occur some losses in the ex post evaluation of the action taken because an optimal timing is not feasible due to unsolved information problems this is no justification for inaction. If there is any lesson to be learned from the recent two bubbles at the beginning of this century it is that. Don't be complacent with regard to global financial market turbulence. Act according the fundamental rules of sustainable economic development and give seemingly short-term benefits much less weight in your decision making. Robust rules for sustainable development in the financial sector should counter the current catastrophic trend of casino capitalism. (see e.g. Stange 1986).

Do we face a super bubble? There is some evidence that the current sequence of bubbles since the mid-1990ies has the scary tendency that overcoming the last bubble (new economy bubble) has triggered an even bigger bubble (financial market bubble caused by securitzation). 


\section{References}

G. W. Ainslie (1975) Specious reward: A behavioral theory of impulsiveness and impulsive control. in: Psychological Bulletin, Vol. 82, 463-496.

George A. Akerlof and Robert S. Shiller (2009), How Human Psychology Drives the Economy, and Why It Matters for Global Capitalism, Princeton University Press, 2009.

George A. Akerlof (1970), The Market for 'Lemons': Quality Uncertainty and the Market Mechanism. in: The Quarterly Journal of Economics. Vol. 84, Issue. 3, August 1970, 488-500.

Miguel Almunia, Augustín S. Bénétrix, Barry Eichengreeen, Kevin H. O’Rourke and Gisela Rua (2009), From Great Depession to Great Credit Crisis: Similarities, Differences and Lessons, Paper presented at the $50^{\text {th }}$ Economic policy Meeting in Tilburg on October 23-24, 2009.

Arthur, W. Brian (1994), Increasing Returns and Path Dependence in the Economy, Ann Arbor, Michigan: University of Michigan Press.

Joseph L.F. Bertrand (1883). "Théorie des Richesses: revue de Théories mathématiques de la richesse sociale par Léon Walras et Recherches sur les principes mathématiques de la théorie des richesses par Augustin Cournot", in: Journal des Savants.

S. Bikhchandani, D. Hirshleifer, and I. Welch (1992), A Theory of Fads, Fashion, Custom, and Cultural Change as Informational Cascades, in: Journal of Political Economy, Vol. 100, Issue 5, 992-1026.

S. Bikhchandani, D. Hirshleifer, and I. Welch (1998), Learning from the Behavior of Others: Conformity, Fads, and Informational Cascades, in: Journal of Economic Perspectives, Vol. 12, Issue 3, 151-170.

S. Bikhchandani, D. Hirshleifer, and I. Welch (2008). Information cascades, in: The New Palgrave Dictionary of Economics, 2nd Edition.

Willem Buiter (2008), Can Central Banks Go Broke? in: Policy Insight No. 24, Centre for Economic Policy Research, London, May 2008.

Phillip Cagan (1956), The Monetary Dynamics of Hyperinflation in: Studies in the Quantity Theory of Money. Ed.Milton Friedman, University of Chicago Press, Chicago 1956.

Edward Hastings Chamberlin (1933), Theory of Monopolistic Competition, Harvard University Press, 1933.

Alfred D. Chandler, jr. (2004), Scale and Scope -The Dynamics of Industrial Capitalism, Harvard University Press, Boston.

Antoine Auguste Cournot (1838), Recherches sur les principes mathématiques de la théorie des richesses (Researches into the Mathematical Principles of the Theory of Wealth), 1838 (1897, Engl. trans. by N.T. Bacon). 
V. P. Crawford and J Sobel (1982), Strategic Information Transmission.in: Econometrica, Vol 50, No. 6, 1431-1451

Douglas W. Diamond and Raghuram Rajan (2009), The Credit Crisis: Conjectures about causes and remedies, NBER-Working Paper 14739, National Bureau of Economic Research, Cambridge, MA, February 2009.

Peter Diamond (1987), Multiple Equilibria in Models of Credit, in: The American Economic Review, Vol. 77, No. 2 (May 1987), 82-86.

Eide Erling, Paul H Rubin and Joanna M Shepherd (2006), Economics of Crime, Now Publishers, Delft, 2006.

Georg Erber, Alexandra Rudolph and Sebastian Weber (2009), Facing a Break Point in Global Inflation Transmission?, SSRN-Working Paper. http://papers.ssrn.com/sol3/papers.cfm?abstract_id=1405327

Joseph Farrell and Paul Klemperer (2004), Coordination and Lock-in: Competition with switching-costs and Network Effects., in: Handbook of Industrial Organization, eds. M. Armstrong and R. Porter, Volume 3, North-Holland, Elsevier, 1970-2071.

Joseph Farrell and M. Rabin (1996), Cheap Talk. in: The Journal of Economic Perspectives, Vol. 10, No. 3. (Summer, 1996), 103-118.

Edgar Feige and James Dean (2002), Dollarization and Euroization in Transition Countries: Currency Substitution, Asset Substitution, Network Externalities and Irreversibility, in: Monetary Unions and Hard Pegs - Effects on Trade, Financial Development and Stability eds. Volbert Alexander, Jacques Mélitz, Georges M. von Fuerstenberg, Centre of Economic Policy Research, Oxford.

Eugene Fama (1970), Efficient Capital Markets: A Review of Theory and Empirical Work, in: Journal of Finance, Vol. 25, 383-417.

Ernst Fehr and Jean-Robert Tyran (2001), Does Money Illusion Matter? in: The American Economic Review, Vol. 91, No. 5 (Dec., 2001), 1239-1262.

Milton Friedman and Anna Jacobson Schwartz (1971), A Monetary History of the United States, 1867-1960, Princeton University Press.

Gerd Gigerenzer and Peter M. Todd (eds.): (1999), Simple heuristics that make us smart. Oxford University Press, New York 1999

Kurt Gödel (1931), Über formal unentscheidbare Sätze der Principia Mathematica und verwandter Systeme, in: Monatshefte für Mathematik und Physik Vol. 38, 173-98.

Alan Greenspan (1996), The Challenge of Central Banking in a Democratic Society, Remarks by Chairman Alan Greenspan at the Annual Dinner and Francis Boyer Lecture of The American Enterprise Institute for Public Policy Research, Washington, D.C, December 5, 1996. http://www.federalreserve.gov/boarddocs/speeches/1996/19961205.htm 
Elhanan Helpman ed. (1998), General Purpose Technologies and Economic Growth, The MIT Press, Cambridge, Mass.

Edward S. Herman and Noam Chomsky (1988), Manufacturing Consent: The Political Economy of the Mass Media, Pantheon Books.

T. P. Hettmansperger and , J. W. McKean (1998), Robust nonparametric statistical methods. Kendall's Library of Statistics. 5 (First ed.). Edward Arnold, .London:

Friedrich A. Hayek (1945), The Use of Knowledge in Society, in: The American Economic Review, Vol. 35, No. 4 (Sep., 1945), 519-530.

John Maynard Keynes (1936), The General Theory of Employment, Interest and Money, Macmillan Cambridge University Press, for Royal Economic Society in 1936.

Charles P. Kindleberger (1978), Manias, Panics, and Crashes: A History of Financial Crises, Wiley, New York.

Dale W. Jorgenson, Kevin J. Stiroh, Robert J. Gordon and Daniel E. Sichel (2000), Raising the Speed Limit: U.S. Economic Growth in the Information Age, in: Brookings Papers on Economic Activity, Vol. 2000, No. 1 (2000), 125-235

Frank H. Knight (1921), Risk, Uncertainty and Profit, Hart, Schaffner \& Marx; Houghton Mifflin Co,. Boston, MA:, 1921.

Roger Lowenstein (2000), When genius failed - The rise and fall of Long-Term Capital Management, Random House, New York.

Burton G. Malkiel (2003), The Efficient Market Hypothesis and Its Critics, in: CEPS Working Papers No. 91, April 2003.

Burton G. Malkiel (1996), A Random Walk Down Wall Street: The Best and Latest Investment Advice Money Can Buy, W. W. Norton \& Company New York.

Alfred Marshall (1890), Principles of Economics, London, Macmillan.

Hyman P. Minsky (1982), Can it happen again? Essays on the Instability of Finance, M. E. Sharpe, Armong, New York.

Hyman P. Minsky (2008), Stabilizing an Unstable Economy, McGraw-Hill, New York.

A. W. Phillips (1958), The Relationship between Unemployment and the Rate of Change of Money Wages in the United Kingdom 1861-1957. in: Economica Vol. 25 (100) 283299.

Paul Masson (2001), Multiple Equilibria, Contagion and the Emerging Market Crisis, in: Financial Crisis in Emerging Markets eds. Reuven Glick, Ramon Moreno and Mark m. Spiegel, Cambridge University Press, 75-97.

Joan Robinson (1933), The Economics of imperfect competition, London: Macmillan, 1933. 
Nouriel Roubini and Stephen Mihm (2010), Crisis Economics - A Crash Course in the Future of Finance, Penguin Press, New York.

Joseph Alois Schumpeter (1922), Theorie der wirtschaftlichen Entwicklung (transl. 1934, The Theory of Economic Development: An inquiry into profits, capital, credit, interest and the business cycle) 1911.

Robert J. Shiller (2000), Irrational Exuberance, Princeton University Press, Princeton.

Robert J. Shiller (2008), The subprime solution - How Today's Global Financial Crisis Happened and What to do about it, Princeton University Press, 2008.

Vernon L. Smith (1976). Experimental Economics: Induced Value Theory, in: The American Economic Review, Vol. 66 (2), 274-279.

Susan Stange (1986), Casino Capitalism, Basil Blackwell, London.

David Stockman (1986), The Triumph of Politics: Why the Reagan Revolution Failed, New York: Harper \& Row, 1986.

Nassim Nicholas Taleb (2007), The Black Swan - The Impact of the Highly Improbable, Penguin, London.

Richard H. Thaler (1994), The Winner's Curse: Paradoxes and Anomalies of Economic Life, Free Press, New York.

Richard H. Thaler (1981) Some Empirical Evidence on Dynamic Inconsistency. in: Economic Letters Vol. 8, 201-07.

Jean Tirole (1988), The Theory of Industrial Organization, The MIT Press. Cambridge, Massachusetts.

James Tobin (1972), Inflation and Unemployment, in: The American Economic Review, Vol. 62, No. 1 (March 1972), 1-18.

Harro von Senger (1993), The Book of Stratagems: Tactics for Triumph and Survival, Penguin Press.

Bob Van Voris (2010), Rajaratnam, Chiesi Seek Order for Details of Charges, Message on Bloomberg/Businessweek Website of June 10, 2010. http://www.businessweek.com/news/2010-06-24/rajaratnam-chiesi-seek-order-fordetails-of-charges.html

Léon Walras, (1874). Éléments d'économie politique pure, ou théorie de la richesse sociale (Elements of Pure Economics, or the theory of social wealth, transl. William Jaffé), 1874. (1899, 4th ed.; 1926, rev ed., 1954, Engl. transl.)

Robert Watts (2009), FBI sweeps into cricket boss Sir Allen Stanford's bank, in: The Sunday Times, February 15, 2009. http://www.timesonline.co.uk/tol/news/world/us_and_americas/article5734080.ece 